\title{
TRADISI UANG ILANG SEBAGAI HUKUM ADAT DALAM PELAKSANAAN PERNIKAHAN DI NAGARI CAMPAGO SELATAN
}

\author{
Riyen Gusti Suparta
}

PPS UIN Imam Bonjol Padang

J1. Jenderal Sudirman No. 15 Padang

e-mail: riyengsuparta@yahoo.com

\begin{abstract}
The Lost Money or Given Money" is called Uang Ilang in term of Minangkabau culture. It is a gift in the form of a sum of money by the bride and groom given to the prospective bridegroom. The payment of "the lost money" is done through intermediary the head of the tribe between the two sides of the family. This tradition of "the lost money" is a customary requirement that must be met by the family of the bride to the prospective groom. The amount of money may vary depending on the request of the head of the tribe or the male family to the prospective bride. There are two aspects that determine the amount of money payments first, the cultural aspects and socioeconomic status. The purpose of this study is to describe how the implementation of traditions of "the lost money" in South Campago District. This research used descriptive method with qualitative approach. Data collection by interview and supported by supporting books related to "the lost money". The result of this research is known that marriage with "the lost money" tradition system is customary law that has been applied to South Campago District community. In the implementation by finding the source of "the lost money" by borrowing, participation from the head of the tribe, helps from the groom if the couple is dating and t"the lost money" be the responsibility of the parents. The high low payment of illicit money for now is also influenced by the social status of the prospective bridegroom but most of the people do traditions of "the lost money" more to the cultural aspect so the number of payers is only as a customary filler only.
\end{abstract}

Kata Kunci: Uang ilang, hukum adat, pelaksanaan perkawinan.

\section{PENDAHULUAN}

$I$ slam telah menganjurkan kepada manusia untuk menikah. Ada banyak hikmah di balik anjuran tersebut, antara lain adalah:

1. Sunnah para Nabi dan Rasul

"Dari Abi Ayyub ra bahwa Rasulullah SAW bersabda, "Empat hal yang merupakan sunnah para rasul: Hinna, berparfum, siwak dan menikah. (HR. At-Tirmizi 1080)"

2. Bagian dari tanda kekuasan Allah. Seperti yang telah dijelaskan di Dalam Al Qur'an, yaitu;

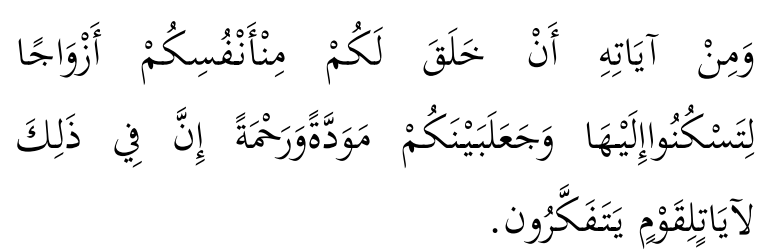

"Dan di antara tanda-tanda kekuasaanNya ialah Dia menciptakan untukmu isteri-isteri dari jenismu sendiri, supaya kamu cenderung dan merasa tenteram kepadanya, dan dijadikan-Nya di antaramu rasa kasih dan sayang. Sesungguhnya pada yang demikian itu benar-benar terdapat tanda-tanda bagi kaum yang berfikir." (Q.S. Ar-Ruum [30]: 21). 
3. Ibadah dan setengah dari Agama.

Dari Anas ra bahwa Rasulullah SAW bersabda, "Orang yang diberi rizki oleh Allah SWT seorang istri shalihah berarti telah dibantu oleh Allah SWT pada separuh agamanya. Maka dia tinggal menyempurnakan separuh sisanya". (HR. Thabarani dan Al-Hakim 2/161).

4. Tidak ada pembujangan dalam Islam.

Islam berpendirian tidak ada pelepasan kendali gharizah seksual untuk dilepaskan tanpa batas dan tanpa ikatan. Untuk itulah maka diharamkannya zina dan seluruh yang membawa kepada perbuatan zina. Tetapi di balik itu Islam juga menentang setiap perasaan yang bertentangan dengan gharizah ini. Untuk itu maka dianjurkannya supaya kawin dan melarang hidup membujang dan kebiri. Mengenai hal ini berkaitan dengan ayat yang ada di dalam Al Qur'an pada QS. Al-Maidah ayat 87 yang artinya;

"Hai orang-orang yang beriman! Jangan kamu mengharamkan yang baik-baik dari apa yang dihalalkan Allah untuk kamu dan jangan kamu melewati batas, karena sesungguhnya Allah tidak suka kepada orang-orang yang melewati batas". (Q.S. Al Maidah [5]: 87).

Sebagian ulama fiqh ada yang berpendapat bahwa kawin itu wajib hukumnya bagi setiap muslim, tidak boleh ditinggalkan selama dia mampu. Menikah itu terkadang bisa mejadi sunnah (mandub), terkadang bisa menjadi wajib atau terkadang juga bisa menjadi sekedar mubah saja. Bahkan dalam kondisi tertentu bisa menjadi makruh. Dan ada juga hukum pernikahan yang haram untuk dilakukan. Semua akan sangat tergantung dari kondisi dan situasi seseorang dan permasalahannya. Apa dan bagaimana hal itu bisa terjadi, (Ahmad Sarwat, 2009: 6-18).

Islam menginginkan pasangan suami istri membina suatu rumah tangga melalui akad nikah bersifat langgeng. Terjalin keharmonisan di antara suami istri yang saling mengasihi dan menyayangi sehingga masing-masing pihak merasa damai dalam rumah tangganya. Dalam ayat lain juga disebutkan seperti dalam Q.S. AdzDzariyat:

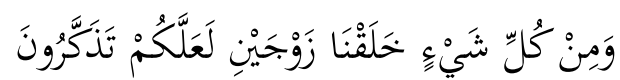

"Dan segala sesuatu kami ciptakan berpasang-pasangan supaya kamu mengingat akan kebesaran Allah". (Q.S. Adz-Dzariyat [51]: 49).

Allah mengatur naluri menetapkan pokok-pokok dan kaedah sehingga dapat memelihara martabat manusia. Manusia harus memelihara keutamaan, kesucian dan keluhuran budi pekerti. Selain itu juga ada hadis Rasulullah menganjurkan untuk Menikah;

"Hai para pemuda, barang siapa diantara kamu mampu kawin, hendaklah kawin, karna perkawinan itu lebih menjaga pandangan dan lebih memelihara kemaluan barang siapa tidak mampu, hendaklah ia berpuasa karena puasa mengendalikan syahwatnya. (HR. Jamaah).

Hukum adat Indonesia beraneka ragam yang dipengaruhi oleh sistem kekerabatan, agama, nilai-nilai dan norma yang berkembang pada masyarakat hukum adat tersebut. Minangkabau adalah salah satu suku yang ada di Indonesia dengan sistem kekerabatan yang disusun menurut tertib hukum ibu. Pernikahan menurut adat Minangkabau adalah pembentukan sebuah keluarga 
yang dilakukan dengan suatu ikatan pribadi antara seorang pria dan wanita melalui restu dan persetujuan dari semua sanak famili.

Menurut Hilman Hadikusuma menyatakan perkawinan dalam perikatan adat adalah perkawinan yang mempunyai akibat hukum adat yang berlaku dalam masyarakat bersangkutan (Hilma Hadikusuma. 2007: 8). Seperti perkawinan dengan sistem tradisi uang ilang yang ada di Nagari Campago Selatan menjadikan uang ilang sebagai persyaratan hukum adat dalam melaksanakan pernikahan. Sebahagian besar ninik mamak mengatakan bahwa uang ilang merupakan syarat dan rukun adat yang harus ada yang merupakan bentuk penghargaan terhadap ninik mamak dan pengahargaan kepada calon mempelai laki-laki.

Nagari Campago Selatan merupakan bagian dari pemerintahan daerah Kabupaten Padang Pariaman. Sebelumnya Nagari Campago Selatan adalah korong Toboh dan bergabung ke kenagarian Campago. Pada tahun 2012 terjadi pemekaran nagari dan Korong Toboh juga ikut serta dalam pemekaran tersebut. Tahun 2016 Kemendagri menerbitkan SK tentang pemekaran kenagarian di Sumatera Barat termasuk korong Toboh. Nagari Campago Selatan merupakan nagari pemekaran sesuai dengan peraturan pemerintahan daerah tahun 2016 tentang produk hukum pemekaran 43 pemerintahan nagari (Arsip Nagari: 2017).

Uang ilang adalah pemberian berupa sejumlah uang oleh calon pengantin wanita yang diberikan kepada calon pengantin laki-laki. Pembayaran uang ilang dilaksanakan melalui perantara ninik mamak antar kedua belah pihak keluarga. Tradisi uang ilang ini merupakan syarat adat yang harus dipenuhi oleh pihak keluarga calon pengantin wanita kepada pihak calon pengantin laki-laki. Jumlah pemberian uang ilang bisa bervariasi tergantung atas permintaan ninik mamak atau keluarga pihak laki-laki kepada pihak calon mempelai wanita (Syaiful, 2018).

Pada sebahagian masyarakat di Campago Selatan ada yang menolak pelaksanaan tradisi uang ilang ini. Masyarakat yang memiliki banyak anak perempuan disebut sebagai baban barek. Keputusan dan kebijakan ninik mamak lebih kuat. Maka masyarakat terpaksa mengikuti apa yang telah menjadi ketentuan adat. Masyarakat yang menolak pelaksanaan tradisi ini memiliki alasanalasan tertentu yang menurut pemikiranya yang benar. Seiring dengan perkembangan waktu masyarakat terus melakukan penyesuaian untuk mempermudah di dalam pelaksanaanya.

Pembayaran uang ilang di Campago Selatan memiliki variasi dalam jumlah tingkatan pembayaran sesuai dengan status sosial dan ekonomi yang dimiliki oleh mempelai laki-laki tersebut. Adanya variasi tersebut menyebabkan masyarakat harus melakukan pernikahan seimbang atau sederajat berdasarkan pertimbangan status sosial dan ekonomi keluarga. Seperti yang di jelaskan oleh Elmanis yang penulis wawancarai di Campago Selatan mengatakan;

“Kalau saya mencari jodoh untuk anak saya sesuai dengan keadaan saya sekarang. Maksudnya saya harus mengukur diri dengan bayang saya. Setidaknya pasangan anak saya adalah 
laki-laki yang seimbang dengan keadaan saya sekarang ini yang mau menerima apa adanya dan yang terpenting ia bertanggungjawab kepada anak dan istrinya. Kalau untuk menerima calon menantu yang berpangkat saya tidak sanggup untuk pembayaran uang ilangnya dan kemana harus saya cari uang sebanyak itu (Elmanis: 2018)."

Jika mempelai wanita berasal dari keluarga yang mampu atau wanita itu berpendidikan bahkan juga memiliki pekerjaan yang sangat baik. Berkemungkinan berpeluang dicarikan jodohnya oleh keluarganya dengan laki-laki yang samasama berasal dari keluarga yang mampu juga. Mereka bisa menikah dengan pasangan yang sederajat. Pembayaran uang ilangnya akan meningkat bahkan lebih mahal. Darneti mengatakan kepada penulis;

"Saya menikah pada tahun 1980, sewaktu itu saya telah memiliki pacar yang bekerja sebagai seorang pedagang. Kami telah pacaran selama empat tahun. Sayangnya orang tua saya tidak merestui hubungan kami karena pacar saya tidak memiliki masa depan kalau bekerja hanya sebagai seorang pedagang karena penghasilanya tidak menentu. Ayah saya seorang pensiunan Pegawai Negeri Sipil di kantor agama di Kota Pariaman. Maka saya dijodohkan dengan seorang laki-laki yang bekerja sebagai pegawai negeri sipil di Kantor Pencatatan Sipil di Kota Pariaman. Uang ilang saat menikah dengan suami saya dulu sebanyak Rp. 600.000. Uang ilang telah disediakan oleh orang tua saya" (Darneti: 2018).

Berdasarkan sumber yang penulis temui pada tahun 1982 telah ada upaya masyarakat, terutama pemerintahan Kabupaten Padang Pariaman yang terkait dengan pelaksanaan tradisi uang ilang. Bahwa pernah diadakan rapat ninik mamak nagari yang dilakukan di Nagari Koto Baru Kecamatan VII Koto Kabupaten Padang Pariaman. Rapat tersebut dihadiri oleh 167 orang yang terdiri dari unsurunsur pemangku adat, alim ulama, cerdik pandai dan bundo kanduang. Pada tanggal 19 Januari 1982 telah diambil sebuah musyawarah dan mufakat untuk menghapuskan tradisi uang ilang dalam sistem pernikahan adat di masing-masing nagari serta menyederhanakan pelaksanaannya. Tetapi di dalam kenyataannya pelaksanaan keputusan penghapusan uang ilang tersebut masih tetap bertahan di dalam kehidupan masyarakat (Maizzia Luth, 1995: 1).

Masalah pembayaran uang ilang telah menjadi kontroversial di dalam lingkungan masyarakat. Sehingga dilakukan upaya oleh pemerintahan Kabupaten Padang Pariaman agar uang ilang yang sudah lama berlangsung bisa dihapuskan di dalam masyarakat, yaitu melalui penyuluhan-penyuluhan berupa anjuran untuk untuk tidak melakukan kebiasaan pembayaran uang ilang. Telah beberapa kali seminar dilakukan untuk membahas permasalahan uang ilang. Seminar lain yang diadakan oleh pemerintahan Kabupaten Padang Pariaman yaitu pembahasan seminar menolak adanya kebiasaan pembayaran uang ilang. Jadi beberapa kelompok masyarakat dan pemerintah daerah telah saling bekerjasama untuk memecahkan permasalahan ini semenjak tahun 1980 (Armaidi Tanjung, 2012: 167).

Tetapi kebijakan pemerintahan Kabupaten Padang Pariaman untuk 
menghapuskan tradisi uang ilang tidak berhasil. Keputusan tersebut dilakukan karena adanya dampak negatif yang muncul akibat tradisi pembayaran uang ilang dalam pernikahan. Banyak kasus yang menyedihkan terjadi, seperti yang dilaporkan oleh Koran Harian Haluan pada tanggal 20 September 1980 dengan judul berita "Gagal Bersanding Gara-Gara Uang Ilang Macet." Kasus ini terjadi di Korong Sungai Jilatang Nagari Campago. Diceritakan bahwa pihak wanita berasal dari keluarga miskin dan ayahnya ingin menjodohkan dengan pemuda yang ada di kampung tersebut. Pemuda itu telah bekerja pada sebuah perusahaan swasta di Pariaman. Keluarga laki-laki meminta uang ilang sebanyak Rp. 300.000. Selain itu laki-laki tersebut juga berpeluang untuk diangkat menjadi calon pegawai negeri sipil. Dalam acara pesta pernikahan berlangsung mempelai laki-laki yang akan dinikahkan dengan wanita tadi tidak datang hingga larut malam maka menangislah mempelai wanita tersebut. Kisah ini dibenarkan oleh Sumarjon kepada penulis karena ia sempat menyaksikan peristiwa tersebut. Sewaktu itu mempelai wanita hanya memberikan uang jemputan saja berupa emas kepada mempelai laki-laki sedangkan uang ilang tidak diberikan karena mempelai wanita tidak sanggup untuk memenuhi permintaan uang ilang tersebut. Awalnya orang tua mempelai wanita akan memberikan uang ilang tetapi pemberianya menyusul setelah diusahakan uang tersebut tidak didapatkan (Sumarjon: 2018).

Larangan pernikahan dengan sistem pembayaran uang ilang tidak ada hukumnya di dalam agama Islam. Menurut Chairuddin mengutip dari buku
Armaidi Tanjung. Dari segi adat uang ilang hanyalah termasuk adat istiadat yang berkembang berdasarkan tiru-tiruan atau gengsi-gengsian. Dalam aspek agama Islam tradisi uang ilang tidak cocok dipandang dari segi asas kemaslahatan, justru Islam mempermudah urusan pernikahan. Hukum Islam menentukan sahnya akad nikah kepada tiga hal yaitu; Dipenuhi semua rukun nikah, dipenuhi syarat-syarat sah nikah dan tidak melanggar larangan pernikahan sebagaimana yang telah ditentukan oleh syari'at, (Ahmad Aiman, 2010: 118).

Melihat pelaksanaan tradisi uang ilang di Kenagarian Campago Selatan yang telah berlangsung sejak lama. Dari pelaksanaan tradisi tersebut terdapat dinamika pola-pola yang beragam dalam mempertahankan eksistensi tradisi uang ilang di dalam masyarakat. Ninik mamak menjadi salah satu unsur pokok yang sangat mempengaruhi pelaksanaan tradisi uang ilang. Meskipun ninik mamak telah mulai kehilangan hegemoninya dalam urusan pernikahan. Berkurangnya peranan ninik mamak sangat dipengaruhi oleh beberapa aspek sosial yang telah berkembang di dalam masyarakat, seperti aspek ekonomi, pendidikan dan lain-lain.

Pelaksanaan tradisi uang ilang di Campago Selatan menjadi sebuah fenomena tradisi budaya yang sangat menarik untuk penulis teliti dalam menjawab petatah adat yang berbunyi "Adat yang indak lapuak dek hujan dan indak lekang dek paneh". Artinya adat yang tidak rapuh oleh hujan dan tidak lekang oleh panas. Terutama penulis perlu melakukan pendekatan sosial kebudayaan dalam perspektif kesejarahan untuk melihat keberlangsungan pelaksanaan tradisi 
uang ilang di Kenagarian Campago Selatan dan siapa saja aktor-aktor yang berperan penting dalam melaksanakan tradisi uang ilang. Meskipun tradisi uang ilang masih tetap bertahan hingga sekarang tetapi ada beragam variasi dalam pelaksanaannya untuk mempertahankan eksistensi tradisi uang ilang. Dalam aspek tertentu dalam pelaksanaan dari tahun ada yang berubah dari pelaksanaan tradisi uang ilang karena dipengaruhi oleh beberapa aspek yang berkembang di dalam masyarakat.

Dari dasar inilah penulis ingin melihat bagaimanakah pelaksanaan tradisi uang ilang dalam pelaksanaan pernikahan yang ada di Campago Selatan. Meskipun telah ada pola perubahan dalam pelaksanaan tradisi tersebut, namun tetap menghormati sistem adat yang berlaku. Pendekatan sejarah yang penulis gunakan dapat melihat aspek apa saja yang saling mempengaruhi dalam proses pelaksanaan uang ilang. Maka penulis mengambil judul penelitian ini dengan nama "Pelaksanaan Tradisi Uang Ilang di Campago Selatan.

\section{METODOLOGI PENELITIAN}

Penelitian ini adalah penelitian kualitatif yaitu serangkaian prosedur penelitian untuk memahami pengalaman manusia dari perspektif perilaku. (IAIN IB Padang, 2014: 29). Dengan langkahlangkah dalam mengumpulkan data dengan cara:

1. Wawancara

Secara umum masyarakat yang penulis wawancarai dapat di kelompokkan kepada:

a. Keluarga yang melaksanakan pernikahan baik dari pihak keluarga perempuan maupun dari pihak keluarga laki-laki yang ada di Kenagarian Campago Selatan.

b. Ninik mamak yang terlibat langsung dalam pelaksanaan tradisi uang ilang yang ada di Kenagarian Campago Selatan

c. Palo modo yang ada di Campago Selatan

d. Tokoh adat

2. Observasi

Penulis akan melakukan observasi langsung ke lapangan tentang tradisi uang ilang dalam pelaksanaan pernikahan di Nagari Campago Selatan.

3. Buku

Sementara itu sumber tertulis lainnya yang merupakan sumber sekunder yaitu melalui studi pustaka (library reseach) dalam melengkapi data kepenulisan. Sumber ini terdiri dari tulisan-tulisan yang menyangkut tentang pelaksanaan tradisi uang ilang. Untuk menguatkan kerangka penelitian, penulis menyusun dengan beberapa variabel yang dianggap terkait dengan penelitian yang penulis lakukan yaitu Buku-buku penunjang seperti buku yang di tulis oleh Bagindo Armaidi Tanjung dengan judul "Kehidupan Banagari di Kota Pariaman", buku A. Navis dengan judul "Adat dan Kebudayaan Minangkabau", Buku Amir Sjarifoedin dengan judul "Minangkabau dari Dinasti Iskandar Zulkarnain sampai Tuanku Imam Bonjol" dan sumber tulisan lain yang dianggap relevan. 


\section{PEMBAHASAN}

\section{Latar Belakang Munculnya Tradisi Uang Ilang}

Pelaksanaan tradisi uang ilang di dalam pernikahan di Kenagarian Campago Selatan merupakan syarat adat yang harus dipenuhi oleh pihak calon mempelai wanita kepada calon mempelai laki-laki. Tradisi ini telah berlangsung semenjak tahun 1970-an, tetapi tidak semua masyarakat saat itu yang melaksanakan tradisi tersebut hanya sebahagian kecil masyarakat saja. Pada tahun 1980 tradisi uang ilang mulai diikuti oleh banyak masyarakat akhirnya menyebar keseluruh kalangan (Hasyim Can: 2018).

Namun ada beberapa asumsi yang dikemukakan oleh masyarakat nagari Campago Selatan munculnya tradisi uang ilang disebabkan karena; Pertama pelaksanaan tradisi uang ilang telah menjadi tradisi kebudayaan turun temurun dari masyarakat terdahulu dan dapat dijadikan sebagai orientasi nilai kebudayaan masyarakat lokal di Kenagarian Campago Selatan. Kedua keluarga yang mampu secara ekonomi pasti menginginkan menantu terpandang baik dari segi pekerjaan maupun dari segi pendidikan. Sehingga keluarga calon mempelai wanita tersebut mampu membayar uang ilang dengan jumlah yang di inginkan pihak keluarga laki-laki agar mau diterima menjadi menantunya. Karena kemapanan ekonomi, pekerjaan dan pendidikan dari calon mempelai lakilaki akan meningkatkan status sosial mempelai wanita tersebut di dalam masyarakat serta menjamim masa depan anaknya yang menikah. Ketiga sebagai balas jasa langsung bagi orang tua laki- laki karena memiliki harapan kepada anaknya nanti setelah dewasa. Anaknya di sekolahkan mulai sekolah dasar hingga perguruan tinggi dengan biaya yang sangat besar agar suatu saat bisa mendapatkan pekerjaan yang baik. Maka orang tua akan mengorbankan semuanya dari segi hal materi. Jika anaknya telah dewasa dan menikah maka tanggung jawab sianak kepada orang tua belum tentu dapat diharapkan karena tanggung jawabnya kepada istri dan anaknya lebih utama. Maka disini orang tua meminta balas jasa kepada calon menantunya dalam bentuk uang ilang.

Jadi ada beberapa unsur yang saling mempengaruhi pelaksanaan tradisi uang ilang di kenagarian Campago Selatan. Salah satu alasan yang tidak dapat dihindarkan adalah dengan menjadikan tradisi uang ilang sebagai orientasi budaya yang telah berlangsung sejak lama. Seperti yang dikatakan oleh Niwat masyarakat Campago Selatan yang penulis wawancarai mengatakan bahwa; “Dalam melaksanakan pernikahan dengan sistem tradisi uang ilang saya hanya mengikuti aturan yang telah ada yang berlaku di dalam masyarakat. Bagaimanapun keadaanya saya yang memiliki anak perempuan harus menyiapkan uang ilang (Niwat: 2018).

Uang ilang sebagai salah satu bentuk balas jasa awalnya berasal dari laki-laki yang bersekolah tinggi. Uang ilang bukanlah kesepakatan adat dan tidak melibatkan persatuan masyarakat hukum adat serta nagari melainkan uang ilang adalah kesepakatan kedua mempelai sebagai bentuk kompensasi kepada pihak keluarga mempelai yang telah bersusah payah membesarkan dan menyekolahkan 
anaknya dan tidak mungkin pihak anak daro dengan istilah tingga ambiak sanang mempelai laki-laki tersebut. Maka diberilah sejumlah uang oleh mempelai wanita kepada mempelai laki-laki sebagai bentuk tanda terima kasih.

Sedangkan menurut versi lain dari beberapa literatur yang penulis temukan juga membahas historisasi uang ilang, salah satunya di dalam buku Amir Sjarifoedin yang membahas tradisi uang ilang di Kota Pariaman. Menyebutkan di India mas kawin dan kasta menjadi permasalahan dalam sistem pernikahan. Telah menjadi tradisi di India bahwa perempuanlah yang mengajukan lamaran dan membeli laki-laki dengan mas kawin yang nilainya cukup besar. Dalam tradisi di India biaya yang harus dikeluarkan tidak hanya saat menyerahkan mas kawin, tetapi juga biaya pernikahan. Maka kenyataan ini seringkali membuat para orang tua yang memiliki anak perempuan akan berusaha mati-matian untuk mengumpulkan uang yang dimulainya ketika anaknya masih kecil. Anak gadis di India harus segera menikah untuk itu orang tuanya sering membayar pihak keluarga calon mempelai laki-laki. Pemberian Mas kawin sebenarnya telah dilarang sejak tahun 1961, tetapi pada prakterknya masih berlaku. Sampai saat ini di India yang mempunyai anak perempuan berarti mempunyai beban. Disebutkan dalam buku Amir Sjarifoedin hubungan antara India dengan Pariaman sudah berlangsung sangat lama. Tercatat dalam sejarah bahwa pada abad ke 12-13 Masehi Pariaman telah menjadi pelabuhan yang baik di pantai barat pulau Sumatra.

Pedagang-pedagang India dan Eropa datang dan berdagang emas, lada dan berbagai hasil perkebunan dari pedalaman Minangkabau lainya. Pariaman kota terpenting memegang peran sebagai enterpot (pelabuhan Gudang) menduduki tempat yang khas dalam konsep geopolitik Minangkabau Tradisional (Suryadi, 2002: 94). Dengan adanya kontak dalam hubungan ekonomigeopolitik hal ini pasti memungkinkan masyarakat luar membangun komunitaskumunitas di daerah Pariaman. Dan hal yang sangat memungkinkan hingga sekarang di Pariaman ada daerah yang bernama kampuang Kaliang yaitu perkampungan India di Pariaman. Dengan masuknya komunitas budaya luar yang hidup bersama-sama dengan masyarakat Pariaman dalam waktu lama memungkinkan terjadinya akulturasi kebudayaan dengan budaya setempat dalam bidang sosial dan budaya yang diwariskan turun temurun hingga sekarang (Amir Sjarifoedin, 2011: 469).

Untuk melihat bagaimana pelaksanaan tradisi uang ilang maka dapat dilihat dari berbagai hal sebagai berikut;

1. Pihak yang Terlibat dan Waktu Menentukan Jumlah Uang Ilang

Untuk menentukan berapa jumlah pembayaran uang hilang yang harus diberikan oleh mempelai wanita kepada mempelai laki-laki secara resmi ditetapkan pada saat acara pertunangan (tukar cincin) oleh ninik mamak keluarga kedua belah pihak calon mempelai laki-laki dan wanita. Dalam kesempatan ini juga dibicarakan persyaratan lain seperti kampia sirih yang harus dibawa oleh keluarga pihak mempelai wanita untuk menjemput mempelai laki-laki pada saat akan melangsungkan akad nikah. Penentuan jumlah uang hilang oleh ninik mamak ini adalah sebagai formalitas saja. 
Karena jauh sebelum penetapan ini, kedua belah pihak terutama orang tua telah bertemu dan membicarakan mengenai jumlah uang hilang tepatnya pada saat maresek.

Tahap-tahap yang harus dilalui dalam menentukan jumlah pembayaran uang ilang secara umum terdiri dari;

a. Menentukan jumlah pembayaran uang ilang yang pertama pada tingkat keluarga inti yaitu antara kedua orang tua. Pada tahap ini jumlah uang ilang mulai dibicarakan. Setelah keluarga kedua belah pihak (pihak keluarga perempuan dan pihak keluarga laki-laki) bertemu dalam proses maresek/ merasok dan setuju hubungan antar keluarga dilanjutkan. Pada tahap ini pihak keluarga lakilaki yang terdiri dari orang tua dan saudara kandung telah merancang jumlah uang ilang yang akan dimintakan kepada keluarga pihak perempuan.

b. Setelah itu dilanjutkan kepada tahap kedua yaitu pada keluarga besar dari mempelai laki-laki. Pada tahap ini proses penentuan uang ilang melibatkan ninik mamak. Ninik mamak tetap diminta masukan dan pertimbangan mereka. Masukan dan pertimbangan itu terutama mengenai pantas dan tidak pantasnya jumlah uang ilang yang akan diminta kepada pihak keluarga perempuan. Setelah pembicaraan tentang penetapan jumlah uang ilang selesai diputuskan oleh pihak ninik mamak dari keluarga laki-laki. Maka barulah disampaikan kepada ninik mamak keluarga wanita dalam pertemuan selanjutnya. Pembicaraan mengenai penentuan uang ilang dapat terjadi dua sampai tiga kali pertemuan. $\mathrm{Hal}$ ini terjadi apabila kedua keluarga belum sepakat mengenai jumlah uang ilang.

2. Waktu Pembayaran Uang Ilang.

Waktu pembayaran uang ilang di Campago Selatan dapat dibagi ke dalam tiga kategori. Hal ini biasanya disesuaikan dengan kemampuan kondisi keuangan keluarga calon mempelai wanita, di antaranya yaitu:

a. Pemberian uang ilang dapat dilakukan beberapa bulan sebelum akad nikah dilangsungkan. Rentang waktu antara satu sampai enam bulan.

b. Pemberian uang ilang setelah pesta pernikahan, pemberian uang ilang yang dibayarkan setelah acara malam baretong atau balambuik.

c. Pemberian uang ilang yang dibayarkan saat menjelang akad nikah

Waktu penyerahan uang ilang ini merupakan hasil mufakat antara ninik mamak keluarga laki-laki dan ninik mamak dari keluarga perempuan. Pemberian uang hilang yang lebih awal biasanya atas permintaan dari pihak laki-laki dengan tujuan agar uang ilang dapat digunakan untuk mempersiapkan segala sesuatu yang berkaitan dengan pelaksaanaan pernikahan nantinya, tetapi pemberian uang ilang seperti ini sudah jarang dipakai.

Pemberian uang ilang setelah pesta pernikahan selesai banyak dipakai pakai tahun 1980. Biasanya mempelai wanita membayarkan uang ilang setelah mendapatkan uang dari malam baretong. Maka uang yang 
didapatkan saat malam baretong yang diambil untuk membayar uang ilang kepada mempelai laki-laki. Sebenarnya juga ada baiknya cara seperti ini apalagi mempelai wanita termasuk keluarga yang tidak mampu. Pemberian uang ilang setelah malam baretong bisa menjadi alternatif.

Setelah cara pertama dan cara kedua dalam sistem pembayaran uang ilang ditinggalkan, masyarakat Campago Selatan setelah itu melakukan pembayaran uang ilang menjelang akad nikah dilangsungkan yakni pada saat calon mempelai lakilaki dijemput ke rumah orang tuanya untuk dinikahkan di rumah calon penganten wanita. Selain kelihatannya lebih sakral juga dirasakan lebih efektif dan efisien. Pembayaran dilakukan oleh ninik mamak atau bisa juga orang tua dari keluarga calon mempelai wanita yang di antarkan langsung ke rumah calon penganten laki-laki beserta keluarga inti lainya. Uang ilang tersebut nantinya akan diterima langsung oleh pihak ninik mamak keluarga calon pempelai laki-laki yang telah menanti di rumah laki-laki. Disaksikan oleh kedua belah pihak keluarga masing-masing seperti mamak, kakak, mande, istri dari mamak dan keluarga inti lainya. Bersamaan dengan itu diserahkan juga persyaratan lainya yaitu kampia siriah (Darneti: 2018).

3. Jumlah Pembayaran Uang Ilang Jumlah pembayaran uang ilang dalam pelaksanaan pernikahan di Campago Selatan memiliki variasi. cenderung mengalami peningkatan mengikuti tinggi rendahnya nilai mata uang yang berlaku masa itu. Tinggi rendahnya jumlah pembayaran uang ilang juga sangat berkorelasi dengan status sosial dan ekonomi dari calon mempelai laki-laki yang merupakan orientasi budaya yang berlaku di dalam masyarakat Campago Selatan. Hal ini tidak dapat dipungkiri lagi karena telah menjadi realita di dalam kehidupan berbudaya masyarakat nagari Campago Selatan.

Mengenai jumlah pembayaran uang ilang di Kenagarian Campago Selatan dapat di tinjau dari dua aspek yaitu

a. Aspek Budaya

Ninik mamak dan keluarga pihak laki-laki tidak akan meminta jumlah yang banyak, melainkan meminta persetujuan dahulu kepada ninik mamak pihak wanita seberapa sanggup ia dapat untuk membayar jumlah uang ilang asalkan adat dapat diisi. Biasannya jumlah pembayaran untuk mengisi adat ini sangat rendah berkisar antara $\mathrm{Rp}$. 5.000.000 sampai Rp. 15.000.000. Jumlah pembayaran sebagai pengisi adat dapat berkurang jika calon mempelai wanita lebih aktif melobi mempelai laki-laki untuk memohonkan kepada mamak dan orang tuannya. Pemberian uang ilang ini dapat dijadikan penutup Tanya masyarakat saja bahwa pernikahan anaknya memakai uang ilang. Jadi masyarakat yang melakukan pernikahan tidak akan merasa malu di hadapan orang lain dengan istilah bahwa pembayaran uang ilang daripado indak ado.

b. Status sosial dan ekonomi

Menunjukkan adanya pembedaan suatu kelompok sosial. 
Misalnya dalam komunitas tersebut ada strata tinggi, Strata sedang dan strata rendah. Pembedaan ini didasarkan kepada adanya suatu simbol tertentu yang dianggap berharga atau bernilai. Baik bernilai secara sosial, ekonomi, politik, hukum dan budaya maupun dimensi lainya seperti kekayaan, pendidikan, jabatan dan pekerjaan (Rizqon Halal Syah Aji, 2015).

Dari pernyataan di atas berdasarkan status sosial dan ekonomi dapat dijelaskan;

1) Pihak keluarga laki-laki dalam menentukan jumlah uang ilang didasarkan atas pertimbangan kelas sosial dan pekerjaan anak laki-lakinya. Dalam hal ini pihak keluarga laki-laki telah memahami bila anak lakilakinya mempunyai status sosial tinggi dari aspek pendidikan dan pekerjaan. Maka uang ilang akan tinggi juga. Maka laki-laki tersebut cenderung untuk mendapatkan calon mempelai perempuan yang menempati posisi yang sama pula dalam status sosial dan ekonomi. Kisaran pembayaran uang ilangnya antara Rp 30.000.000 sampai 50.000.000 juta. Pekerjaanya adalah pegawai negeri sipil, polisi dan TNI atau dokter. Meskipun juga ada terdapat perkawinan yang tidak seimbang itupun dengan pertimbangan-pertimbangan tertentu seperti; kepribadian, agama dan kecantikan dari calon mempelai wanita dan kasus ini sangat jarang terjadi di Campago Selatan.

2) Laki-laki yang memiliki kemampuan dan pekerjaan yang kurang mapan atau pekerjaanya serabutan seperti buruh harian lepas atau pekebun. Maka calon mempelai wanita yang ia dapatkan seimbang dengan kondisi status sosial dan ekonomi laki-laki tersebut. Jumlah pembayaran uang ilangnya antara Rp. 3.000 .000 sampai Rp.10.000.000 juta. Bahkan ada yang tidak memakai uang ilang jika pernikahan diawali dengan pacaran atau suka sama suka.

4. Sumber Pembayaran Uang Ilang

Adapun sumber pembayaran uang ilang di Campago Selatan dapat dikategorikan ke dalam beberapa bentuk yaitu;

a. Pinjaman

Bagi keluarga yang tidak mampu harus membayarkan uang hilang dengan cara berhutang kepada orang lain apalagi jika mempelai wanita yang tidak memiliki mamak. Uang bisa dipinjam kepada tetangga maupun keluarga pengantin wanita yang lain. Seperti yang dituturkan oleh Yusnaini yang penulis wawancarai:

"Sewaktu saya menikah dengan suami saya pada tahun 1987 saat itu keadaan ekonomi sangat sulit saya menikah dengan meminjam uang tetangga sebanyak 400 ribu rupiah supaya pernikahan saya terlaksana. Setelah pesta saya selesai hutang uang ilang baru 
bisa saya lunaskan dengan cara menyicil pada tetangga saya, itupun masih kurang karena uang yang saya dapatkan saat malam baretong atau balambuik tidak mencukupi untuk menutupi biaya pesta dan mengganti biaya uang ilang (Yusnani; 2018)."

Kalau untuk zaman sekarang sistem pinjam-meminjam sudah mulai berkurang. Ekonomi telah membaik karena terbukanya peluang untuk merantau mencari penghidupan ekonomi yang lebih baik. Masyarakat bekerja sebagai pedagang bahkan masyarakat nagari Campago Selatan banyak yang menjadi pedagang sukses. Mereka membuka rumah makan, ada yang memiliki konveksi pakaian dan tingkat pendidikan semakin maju dan memberi peluang bekerja di perusahaan swasta dan pemerintah. Maka pembayaran uang ilang tidak menjadi permasalahan. Beberapa masyarakat ada melakukan peminjaman silang. Jika anak perempuannya menikah maka orang yang meminjamkan uang akan memberikan sejumlah uang untuk pembayaran uang ilang. Suatu saat jika anak perempuan yang telah meminjamkan uang tersebut menikah juga maka orang yang telah meminjam uang tersebut menggantinya di saat pernikahan anak yang telah meminjamkan uang. Pelaksanaan seperti ini juga memberikan kemudahan, tetapi peminjaman seperti ini terjadi antar keluarga dekat atau antar keluarga inti agar pelaksanaannya semakin dipercayai karena sesama saudara mereka telah saling mempercayai.

b. Ninik mamak

Ninik mamak memiliki wewenang yang cukup besar dalam mengatur pelaksanaan tradisi uang ilang di Kenagarian Campago Selatan. Orang tua yang ingin menikahkan anaknya yang sudah cukup umur akan di ambil alih tanggung jawab pernikahannya oleh ninik mamak dalam keluarga tersebut, apalagi anak perempuan. Baik untuk menikahkan anak perempuan maupun anak laki-laki. Mamak lebih cenderung memberikan bantuan dan bertanggung jawab jika kemenakanya membutuhkan. Keterlibatan mamak sangat penting dalam pelaksanaan pernikahan dengan tradisi uang ilang jika pernikahan melalui sistem perjodohan, uang ilang menjadi tanggung jawab ninik mamak kaum perempuan yang hendak menikah. Jika pihak mamak wanita telah menemukan jodoh yang sesuai dengan kriteria yang telah disepakati, maka wanita tersebut tinggal mengiyakan pilihan mamaknya.

Biasanya mamak perempuan akan berembuk dan mulai mencarikan sumber dana jauh-jauh hari sebelum uang ilang tersebut dibayarkan menjelang akad nikah dilangsungkan. Jika keluarga calon mempelai wanita memiliki empat orang mamak sedangkan uang ilang sebanyak Rp. 2.000.000 maka keempat mamak tersebut membagi jumlah pembayaran uang ilang sesuai kemampuan bahkan ada yang membagi sama rata untuk memenuhi jumlah sebanyak Rp. 2.000.000 tersebut (Nasril; 2018). 
c. Mempelai Laki-Laki

Untuk melihat pelaksanaan tradisi uang ilang di Campago Selatan dapat dilihat dari berbagai sikap-sikap yang muncul dari pembayaran uang ilang di dalam masyarakat antara lain:

1) Calon pengantin laki-laki membantu uang ilang sepenuhnya kepada calon pengantin wanita

2) Calon pengantin laki-laki membantu uang ilang sebagian kepada calon pengantin wanita

3) Calon pengantin laki-laki memberikan usulan kepada orang tuannya mengenai jumlah uang ilang.

Pertama calon pengantin lakilaki akan memberikan sejumlah uang kepada pihak perempuan sebanyak jumlah uang ilang yang diminta oleh keluarga laki-laki. Sikap ini dilakukan karena calon pengantin laki-laki yang berekonomi baik dan benar-benar mencintai pasanganya dan laki-laki tersebut pasti akan berkorban untuk pasanganya. Bantuan calon pengantin laki-laki ini dalam menanggulangi uang hilang karena situasi yang tidak mendukung. Dari pihak keluarganya bersikeras meminta uang ilang sebagai syarat adat di dalam pelaksanaan pernikahan. Sementara dari pihak perempuan tidak mempunyai kesanggupan untuk memenuhinya, meskipun pihak laki-laki tersebut telah mengusulkan kepada orang tuanya untuk mengurangi jumlah uang ilang tetapi tidak berhasil maka inilah langkah yang harus diambil oleh calon mempelai laki-laki tersebut asalkan pernikahan tetap berjalan dengan baik. Bantuan ini bersifat kerahasiaan yang tahu hanya kedua mempelai saja.

Pemberian uang ilang secara penuh dari calon mempelai laki-laki kepada calon mempelai wanita agar terlaksananya pernikahan di Kenagarian Campago Selatan dapat dilakukan dengan dua cara:

1) Uang ilang diserahkan secara langsung dan tunai kepada calon pengantin perempuan. Kemudian uang ilang yang diterima dari calon pengantin laki-laki diserahkan kepada orang tua wanita, agar pada saat pernikahan uang ilang itu dapat diserahkan kepada pihak ninik mamak atau keluarga laki-laki sebagai syarat membawa calon pengantin lakilaki untuk melakukan akad nikah. Terkait dengan asal usul sumber uang ilang pemberian pada cara pertama ini dilakukan secara sembunyi-sembunyi tanpa diketahui oleh pihak keluarga dari calon mempelai laki-laki. Pemberian bantuan uang ilang harus hati-hati. Pihak wanita harus berpandai-pandai merahasiakannya dari ninik mamak dan keluarga besar laki-laki. Jadi kesanya uang ilang yang akan diberikan dari mempelai keluarga perempuan kepada pihak laki-laki pada saat menjemput marapulai seolah-olah uang itu berasal dari keluarga wanita. Kerahasiaan asal usul uang ilang harus di jaga oleh kedua mempelai. Kalau tidak 
akan memberi kemungkinan cekcok oleh ninik mamak dari pihak laki-laki karena berkaitan dengan harga diri mamak.

2) Uang ilang yang diberikan secara berangsur-angsur dan sembunyisembunyi. Calon penganten lakilaki seperti ini memiliki ekonomi yang sedang dan akan sangat memberatkan sekali jika bantuan uang ilang diberikan secara tunai. Pembayaran cara kedua ini bisa dimulai saat masa pacaran atau setelah pertunanganan. Pihak calon mempelai laki-laki akan menyicil sesuai kesepakatan keduanya. Tentang jumlah cicilan pembayaran uang ilang tergantung kondisi keuangan calon mempelai laki-laki. Bantuan dari laki-laki ini masih alasan yang sama karena pihak wanita berekonomi sedang atau memang benar-benar tidak mau dibebankan dengan pembayaran dengan sistem uang ilang, terutama membebankan orang tua. Jika wanita tersebut tidak memiliki mamak maka harapan untuk meminta bantuan uang ilangpun tidak ada. Jadi salah satu harapan besar dari wanita adalah kepada pihak laki-laki jika dia benarbenar ingin menikah dengan pasanganya. Sebagai syarat adat uang ilang harus dipenuhi.

Kedua laki-laki memberikan bantuan uang ilang separoh harga dari jumlah uang ilang yang diminta oleh pihak keluarga mempelai lakilaki. Pemberian ini dilakukan sebelum pernikahan dilangsungkan dan masih diberikan secara sembunyi tanpa diketahui oleh pihak keluarga besar laki-laki. Sebenarnya cara kedua ini masih sama prosesnya dengan cara pertama. Uang diberikan kepada calon pengantin perempuan dan selanjutnya diserahkan kepada orang tuanya sebagai penambah uang ilang yang telah disediakan sebelumnya.

Bantuan cara kedua ini sering terjadi di Kenagarian Campago Selatan dalam sistem pembayaran uang ilang. Kedua mempelai telah saling memahami keadaan ekonomi masing-masing keluarga. Pihak wanita tidak terlalu membebankan pembayaran uang ilang secara penuh kepada laki-laki. Bagaimanapun dari calon penganten wanita harus menyediakan uang ilang seberapa adanya. Pada saat akad nikah dilangsung uang ilang tetap dibunyikan sejumlah yang diminta pada kesepakatan awalnya oleh pihak keluarga laki-laki, meskipun uang ilang itu berasal dari bantuan calon penganten laki-laki sebanyak separuh harga.

Ketiga calon pengantin laki-laki memberi usulan kepada orang tuanya mengenai jumlah uang hilang. Usulan ini untuk pengurangan jumlah uang hilang yang harus dibayarkan oleh mempelai perempuan. Cara ini dilakukan oleh pengantin laki-laki karena menyukai pasangannya tetapi kurang mampu dari segi ekonomi. Usulan mengenai pengurangan uang hilang dilakukan sebelum tukar cincin dan calon pengantin laki-laki dengan langsung 
menyampaikan kepada orang tuanya. Ketika ada pertemuan orang tua kedua belah pihak orang tua dari pihak laki-laki dapat mempertimbangkan usulan dari anaknya dan menyampaikan sesuai dengan kesepakatan orang tua dan anakya yang telah dibicarakan sebelumnnya (Rori, 2018).

d. Orang Tua

Pembayaran uang ilang yang berasal dari orang tua dilakukan oleh orang tua yang memiliki kemampuan ekonomi yang baik atau pihak perempuan yang tidak memiliki mamak, meskipun ada mamak tetapi lebih cuek. Pernikahan melalui sistem pembayaran dari orang tua diawali dengan perjodohan, meskipun ada sebahagian memulainya dengan pacaran. Untuk memecahkan permasalahan ini salah satu jalan keluarnya adalah orang tua wanita harus menyediakan uang ilang sesuai dengan jumlah yang telah disepakati oleh masing-masing keluarga (Asnayenti; 2018).

Masyarakat Campago Selatan telah menyadari jika memiliki anak perempuan disebut dengan baban barek. Untuk mengantisipasi keadaan yang sulit saat anaknya menikah, mereka mulai mempersiapkan uang ilang. Tidak ada mamakpun tidak apa-apa karena orang tua telah tahu dengan tanggungjawabnya. Ada beberapa macam tindakan yang diambil orang tua dalam melaksanakan sistem pembayaran uang ilang di Campago Selatan, di antaranya;
1) Orang tua menyiapkan uang ilang karena di dalam keluarganya tidak ada mamak yang akan menolong pembayaran uang ilang. Meminta bantuan kepada orang lain sesuatu hal yang tidak mungkin dilakukan kecuali ada partisipasi dari keluarga saparuik dari orang tua wanita. Mamak telah sibuk mengurus urusannya sendiri bahkan tidak peduli lagi dengan kemenakan perempuanya

2) Orang tua menyiapkan pembayaran uang ilang didukung kondisi ekonomi yang baik misalnya kedua orang tuanya bekerja sebagai PNS, aparat pemerintah atau pengusaha. Penghasilanya bisa dijadikan untuk pembayaran uang ilang anaknya yang akan menikah, maka tidak perlu meminta bantuan mamak atau keluarga lain. Orang tua merasa mampu untuk menyelesaikan permasalahan ini sendiri.

\section{PENUTUP}

\section{Kesimpulan}

Pelaksanaan tradisi uang ilang di Campago Selatan mempertimbangkan dua nilai yang dianggap penting yaitu nilai ekonomi yang berkaitan dengan status sosial dan nilai budaya yang berkaitan dengan tradisi turun-temurun yang telah berlangsung sangat lama. Kedua bentuk nilai itu menjadi prinsip dasar pada kedua belah pihak keluarga yang melakukan tradisi uang ilang. 
Untuk mempertahankan pelaksanaan tradisi uang ilang di Nagari Campago Selatan dapat dilakukan dengan mewarisi (sosialisasi) dan menanamkan nilai-nilai (integrasi) yang ada dalam masyarakat. Jumlah pembayaran uang semakin meningkat seiring dengan semakin tingginya status sosial ekonomi seorang mempelai laki-laki.

Pelaksanaan tradisi uang ilang di Kenagarian Campago Selatan dalam pernikahan telah menjadi sebuah tradisi kebudayaan yang diwariskan secara turun temurun oleh masyarakat. Pelaksanaanya sudah ada semenjak tahu 1970 hingga trend berkembang luas pada tahun 1980 . Pelaksanaan tradisi uang ilang berlangsung dengan sejumlah variasi dan penyederhanaan.

\section{Saran}

1. Perlu adanya aturan adat yang tegas dibuat oleh pemuka adat seta niniakmamak dengan memberikan sosialisasi pada anak-kemenakannya atas maksud dan tujuan pelaksanaan tradisi uang ilang yang dilaksanakan di dalam pernikahan.

2. Diperlukan adanya partisipasi (solidaritas) dari anggota keluarga besar, agar dapat menanggulangi uang ilang yang terus meningkat seiring dengan meningkatnya status sosial laki-laki yang akan dijadikan menantu.

3. Seharusnya masyarakat, ninik mamak dan orang tua tidak terlalu memaksakan permintaan uang ilang kepada calon mempelai yang tidak mampu untuk memenuhinya.

4. Jika pelaksanaan tradisi uang ilang telah menjadi kesepakatan bersama sebagai syarat adat dalam pelaksanaan pernikahan di Kenagarian Campago
Selatan, seharusnya kedua calon pengantin telah mempersiapkan jauhjauh hari uang ilang tersebut sebelum pernikahan dilangsungkan.

5. Menurut KAN seharusnya uang ilang ini tidak memiliki manfaat karena akan membebani pihak wanita kalau dapat dihilangkan saja.

\section{DAFTAR KEPUSTAKAAN}

Aiman, H. Ahmad," Itsbat Nikah dalam Hukum Perkawinan di Indonesia" Jurnal Darussalam, Volume 10, No 2, (Juli-Desember 2010)

Arsip Nagari Campago Selatan Tahun 2017

Hadikusuma, Hilma, Hukum Perkawinan Indonesia Menurut Perundangan Hukum Adat, hukum Agama, (Bandung: Masdar Maju, 2007)

Halal Syah Aji, Rizqon, Stratifikasi Sosial dan Kesadaran Kelas, Jurnal Sosial dan Budaya vol.2 No.1 UIN Syarif Hidayatullah Jakarta, ISSN:2356 (Juni, 2015)

IAIN IB Padang, Pedoman Penulisan Karya Ilmiah, (Padang, 2014)

Luth, Mazzia," Mengatur Masalah Pembayaran Perkawinan di Daerah Pariaman" FPIPS-IKIP Padang, (Juni, 1995)

Sarwat, Ahmad, "Seri Fiqih Islam, Kitab Nikah," Cet 1 (Kampus Syari'ah, September, 2009)

Sjarifoedin, Amir, Minangkabau dari Dinasti Iskandar Zulkarnain sampai Tuanku Imam Bonjol, (Jakarta: Graha Media, 2011) 
Suryadi, Syair Sunur, teks dan Konteks Otobiografi Seorang Ulama Minangkabau abad 19 (Padang: PPIMC, 2002)

Tanjung, Bagindo Armaidi, Kehidupan Banagari di Kota Pariaman, (Pariaman, Bappeda Kota Pariaman, 2012)

Elmanis, Masyarakat Nagari Campago Selatan, wawancara, Selasa, 2 Januari 2018

Darneti, Masyarakat Nagari Campago Selatan, wawancara, Selasa, 2 Januari 2018

Sumarjon, Wali Nagari Campago Induk, wawancara, Selasa, 2 Januari 2018

Rory, Masyarakat Nagari Campago Selatan, wawancara, Kamis, 4 Januari 2018
Syaiful, Palo Mudo di Nagari Campago Selatan, wawancara, Kamis, 4 Januari 2018

Hasyim Can, Tokoh Adat, Dt. Rajo Panghulu, wawancara, Jum'at, 5 Januari 2018

Niwat, Masyarakat Nagari Campago Selatan, wawancara, Minggu, 7 Januari 2018

Nasril, Mamak di Nagari Campago Selatan, wawancara, Kamis, 1 Februari 2018

Yusnani, Masyarakat, wawancara, Kamis 1 Februari 2018. 